\title{
BOEKBESPREKING
}

Album van het eiland Aruba. Samengesteld en uitgegeven door S. J. Teunisse bij de viering van den 300 -jarigen band tusschen het gebiedsdeel Curaçao en Nederland in Juli van het jaar 1934.

Gedrukt bij de drukkerij „De Spaarnestad" Haarlem.

In de inleiding tot dit fraai uitgevoerde album geeft de samensteller - in het Nederlandsch, het Engelsch en het Spaansch in een kort bestek een toch inderdaad zeer veelzijdig overzicht van de gesteldheid van Aruba, na Curaçao het belangrijkste eiland van de groep der Nederlandsche Antillen.

Wie zich bewust is van de wenschelijkheid om actueele bijzonderheden aangaande ons eilandengebied in de Caraibische Zee onder de oogen van het groote publiek te brengen, zal reeds dit enkele blaadje druks met vreugde begroeten, als een waardevolle aanwinst voor de op dit gebied betrekking hebbende litteratuur.

In De West-Indische Gids van April d. j. gaf H. A. Hessling een Beeld van Aruba in Cijfers, in Juni d.a.v. wist Teunisse, bij de introductie van zijn album, die cijfers aan te vullen met interessante algemeene bijzonderheden. De beide publicaties te zamen geven ons den toestand van het eiland Aruba, bij den aanvang van het Curaçaosche herdenkingsjaar 1934, een toestand welke, door middel van het Verslag van Bestuur en Staat (Curaçao), wel niet vóór tweede helft 1935 officieel zal worden blootgelegd.

Het album bevat twee portretten, van den Gouverneur van Curaçao en van den Gezaghebber van Aruba, een kaartje van het eiland en verder een aantal goede foto's, verdeeld in vijf rubrieken.

In de eerste rubriek zijn opgenomen 19 afbeeldingen van Oranjestad, de hoofdplaats van het eiland, in de tweede 7 van het dorp St. Nicolaas, aan de baai van dien naam, dat zoo sterk 
is opgekomen door de. vestiging van het petroleumindustriebedrijf, in de derde 23 van de buitendistricten op het eiland, in de vierde 14 van de concessie der Lago Oil and Transport Comp. Ltd. en in de vijfde 3 op de sport betrekking hebbende, welke laatste met de olienijverheid haar intrede heeft gedaan op Aruba.

Alle afbeeldingen zijn goed geslaagd en actueel.Van het Nederlandsche oliebedrijf op Aruba (de Arend Petroleum Maatschappij) bevat het album echter niets op het gebied van illustraties.

Negen handelsondernemingen en een tandarts adverteeren niet alleen in het album, maar zij illustreeren hun annonces met afbeeldingen hunner kantoren, magazijnen en vestigingsplaatsen en dragen er zoodoende toe bij ons een beeld te geven van het moderne Aruba.

Het ware te wenschen dat er op de Nederlandsche Antillen wat vaker een aanleiding werd gevonden om zich door woord en beeld meer bekendheid in de buitenwereld te verschaffen en ook dat bij deze gelegenheid andere eilanden der groep het voorbeeld van Aruba hadden gevolgd.

W. R. Menkman.

Jubileum-Album bevattende 5 Curaçaosche Penteekeningen vervaardigd door Hollandsche Artisten, 1 Reproductie Historische Curaçaosche Penteekening.

Ontwerp: J. Tyssen, Den Haag, Holland. Uitgave: Fotohandel ,Sunny Isle”, L. Reck, Curaçao, (N. W. I.).

Kort na het Aruba-album gewerd mij dit Jubileum-Album. Ook op het ,hoofdeiland" dus heeft men de herdenking van 1934 aangegrepen als een gelegenheid om aan de buitenwereld een voorstelling te geven van hoe het er daarginds uitziet.

De uitgever is bekend door de serie mooie Curaçaosche prentbriefkaarten welke hij al eerder de wereld had ingezonden.

Sunny Isle is inderdaad een op Curaçao zeer toepasselijke naam, maar het spreekt wel van zelf dat die zonnigheid in penteekeningen niet wel tot haar recht kan komen. Ook beelden deze teekeningen niet uit de tegenwoordige bedrijvigheid op Curaçao, de groote vlucht welke industrie en scheepvaart hebben genomen, de moderniseering van verkeer, huisvesting, amuse- 
ment enz. van den laatsten tijd, maar dat kan ook niet de bedoeling zijn geweest der uitgave.

Het gezicht op de Handelskade vertoont geen enkel stoom- of motorschip,dat de haven in- of uitvaart, auto's krijgen wij niet te zien, maar wel een waterverkooper die, met zijn bokooi op een ezelwagentje, langs de huizen leurt; wij kunnen ons niet verlustigen in den aanblik van nieuw aangelegde moderne verkeerswegen, of van de meest recente creaties op het punt van huizenbouw, maar het landschap bij den $Z$ warten Berg en het straatje in Otrabanda zijn zoo typisch Curaçaosch als maar mogelijk is en dit Curaçao is natuurlijk nog lang niet verdwenen en zal ook wel niet zoo spoedig verdwijnen.

Dat er niet opzettelijk naar gestreefd is uit te beelden hetgeen vergaan is, bewijst de teekening van het Gouvernementshuis, waarop men duidelijk de hooge lantaarnmasten waarneemt der gemoderniseerden electrische verlichting.

De historische prent ten slotte welke in het album is gereproduceerd, is die in het National Maritime Museum te Greenwich in Engeland, vertoonende ,'t Eyland Curaçao Anno 1786", gezien van zee uit en met een 40 tal verklarende onderschriften. Curaçaosche afbeeldingen van vóór de 19e eeuw zijn schaarsch genoeg om de reproductie van deze zeldzame prent, waarvan er voor zoover mij bekend is in Nederland geen aanwezig is, met voldoening in het album opgenomen te zien.

Dit Jubileum-Album is een unicum, niet alleen omdat het ter gelegenheid eener zoo bijzondere herdenking is uitgegeven. Het is een artistieke uitgave welke ieder die Curaçao kent gaarne in zijn bezit zal hebben en iedere tourist gaarne van daar als een souvernir zal medenemen.

W. R. Menkman

H. J. Wolff, Historisch Overzicht over Suriname 1613-1934.

Dezer dagen verscheen van de hand van den heer H. J. Wolff, oud-districtssecretaris van Suriname, een werkje dragende den hierbovengenoemden titel.

De stof wordt in drieën ingedeeld en wel: le deel, bevattende de geschiedenis van het verleden; $2 \mathrm{e}$ deel, die van het heden; $3 \mathrm{e}$ deel, allerlei economische en statistische gegevens en lezingen over Surinaamsche onderwerpen, door deskundigen gehouden. Voorts treffen wij in dit deel nog namen van vereenigingen aan, die in 
Nederland streven naar meer belangstelling voor de West-Indische koloniën.

Daar de geschiedenis in dit werkje een geringere plaats inneemt dan de titel zou doen vermoeden, zouden wij het liever willen noemen: „Een handleiding (of: Leiddraad) van Suriname”. Het minst betrouwbaar is volgens onze meening het historisch gedeelte. Wij bedoelen hiermede het eerste en het tweede deel. De schrijver heeft teveel gebruik gemaakt van tweedehandsche bronnen. Daardoor schreef hij op pag. 10: „Omstreeks 1630 verkreeg de WestIndische Compagnie een octrooi om slaven aan Suriname te leveren". In geen enkele resolutie der Staten-Generaal hebben wij van het door den schrijver bedoeld octrooi gelezen. Wel vonden wij op pag. 634 en 221 van de Encyclopædie van Ned. W e s t-I n d i ë, dat vóór 1640 de slavenhandel hoofdzakelijk in handen der Portugeezen en Spanjaarden was en pas na $1640 \mathrm{Hol}-$ landsche particulieren dezen handel krachtiger ter hand namen. Bij de overdracht der rechten van Zeeland aan de tweede WestIndische Compagnie, lezen wij voor het eerst in de resolutie der Staten-Generaal van een octrooi betreffende den slavenhandel. „Dat dewijle de gemelte Colonie ${ }^{1}$ ) niet wel kan werden voortgeset, dan door middel van zwarte slaven ofte Negros ende dat niemandt buyten de voorsz. Compagnie in dese Landen bevoeght is eenige slaven te halen van de kuste van Africa alwaer alleen ingehandelt werden, soo sal de voorsz. Compagnie geobligeert zijn aen geseyde Colonie jaerlycx te leveren sodanigen aental slaven, als aldaer sullen wesen gerequireert". (Octroy 1682, Art VI). Daar hierin niet gesproken wordt van een voorafgaand octrooi, kunnen wij aannemen, dat zulks niet bestaan heeft. Een andere onjuistheid is, dat Bonham (1811-1816) na het incident tusschen hem en Halfhide op 31 Mei 1813 in de vergadering van het Hof van Politie het Hof ontbond (zie pag. 26). Indien de schrijver de bronnen had geraadpleegd, zou hij deze mededeeling nooit gedaan hebben. In zijn rapport over het gebeurde aan Lord Bathurst gericht, schreef Bonham: „I then rang the Bell \& broke up the Court" 2). Broke up te Court wil niet zeggen ontbond het Hof, maar hief de zitting op. Niet de Schout bij Nacht Willem Benjamin van Panhuys vertrok eind 1815 naar de West om Suriname voor Nederland van de Engelschen over te nemen, doch de Generaal-Majoor van Panhuys. De Vice-Admiraal, die meeging, heette van Braam.

1) Suriname.

2) Brief van 31 Mei 1813 
Het laatste deel van dit werkje is belangrijker en geeft den lezer meer voldoening. De gegevens zijn hier betrouwbaarder dan in de eerste twee deelen. Vooral zij, die over den in- en uitvoer iets willen weten, vinden hierin overvloedig materiaal. Ondanks de gebreken, kunnen wij dit propagandistisch geschrift ten zeerste aanbevelen.

\section{J. EINAAR}

Dr. S. L. van der Wal, De motie-Keuchenius. Een Koloniaal-historische studie over de jaren I854-I866. Utrechtsche bijdragen tot de geschiedenis, het staatsrecht en de economie van Nederlandsch-Indie I. N.V. J. B. Wolters' uitgevers-maatschappij, 1934.

De redactie heeft even geaarzeld, of dit boek, ons ter beoordeeling toegezonden, besproken moet worden in ons tijdschrift, dat de West tot voorwerp van studie wil gemaakt zien. Echter - de motie-Keuchenius heeft wel betrekking op een Oost-Indische aangelegenheid, de benoeming van den pas opgetreden minister van Koloniën Mijer tot gouverneur-generaal, maar raakt in wezen een zaak van koloniaal regeeringsbeleid, die zich even goed ten opzichte van Suriname en Curaçao kan voordoen. Dr. Van der Wal behandelt de kwestie van de al of niet grondwettigheid der motie intusschen slechts incidenteel. Keuchenius en de opkomst der antirevolutionaire koloniale politiek maken de hoofdschotel dezer goed geschreven en prettig leesbare studie uit. Dit nu valt buiten ons kader, en daarom moet met deze aankondiging worden volstaan.

B. DE GAAY FoRTMAN 